\title{
HIGH COFFEE POPULATION DENSITY TO IMPROVE FERTILITY OF AN OXISOL ${ }^{1}$
}

\author{
MARCOS ANTONIO PAVAN² , JÚLIO CÉSAR DIAS CHAVES, RUBENS SIQUEIRA, \\ ARMANDO ANDROCIOLI FILHO, ARNALDO COLOZZI FILHO ${ }^{3}$ and ELCIO LIBORIO BALOTA ${ }^{4}$
}

\begin{abstract}
The objective of this work was to evaluate the effect of coffee (Coffea arabica L.) population densities on the chemical and microbiological properties of an Oxisol. The work was carried out on soil samples of 0-20 cm depth originated from an experimental site which had been used for coffee tree spacing studies during 15 years, in Paraná State, Brazil. Eight coffee tree populations were evaluated: $7143,3571,2381,1786,1429,1190,1020$, and 893 trees/ha. Increasing plant population increased soil $\mathrm{pH}$, exchangeable $\mathrm{Ca}, \mathrm{Mg}, \mathrm{K}$, extractable $\mathrm{P}$, organic carbon, moisture content and coffee root colonization by vesicular arbuscular mycorrhizal fungi, and decreased exchangeable $\mathrm{Al}$ and microbial biomass. Such results were attributed to better erosion control, improved plant residue management and nutrient cycling, and decreased leaching losses. Increasing coffee tree population per unit of area has shown to be an important reclamation recuperation strategy for improving fertility of the acid soils in Paraná, Brazil.
\end{abstract}

Index terms: Coffea arabica, acid soil, tree spacing,

\author{
DENSIDADE POPULACIONAL DE CAFEEIROS \\ PARA MELHORAR A FERTILIDADE DE UM LATOSSOLO
}

\begin{abstract}
RESUMO - O objetivo deste trabalho foi verificar os efeitos de diferentes densidades de população de cafeeiros (Coffea arabica L.) nas propriedades químicas, físicas e microbiológicas do solo. Amostras de um Latossolo foram coletadas na profundidade $0-20 \mathrm{~cm}$ em um experimento de campo onde estavam sendo avaliadas diferentes populações de cafeeiros. Os tratamentos foram 7.143, 3.571, 2.381, 1.786, $1.429,1.190,1.020$ e 893 covas/ha. Os resultados demonstraram que o aumento da população de plantas por unidade de área aumentou o $\mathrm{pH}, \mathrm{o} \mathrm{Ca}$, o $\mathrm{Mg}$ e o $\mathrm{K}$ trocáveis, o $\mathrm{P}$ disponível, o carbono orgânico, o teor de umidade e a colonização radicular por micorrizas, e diminuiu o Al trocável e a biomassa microbiana. Foram considerados como causas da melhoria da fertilidade do solo, sob cafeeiros adensados, o adequado controle da erosão, o correto manejo dos resíduos vegetais e a baixa lixiviação dos íons. O manejo da população de cafeeiros pode constituir uma estratégia importante para a recuperação da fertilidade dos solos ácidos do Paraná.
\end{abstract}

Termos para indexação: Coffea arabica, solos ácidos, espaçamento.

\section{INTRODUCTION}

In the state of Paraná, Brazil, soil acidity is an ongoing process in soils planted with coffee (Coffea arabica L.)

${ }^{1}$ Accepted for publication on July 7, 1998.

${ }^{2}$ Agronomist, Ph.D., Instituto Agronômico do Paraná (IAPAR), Caixa Postal 481, CEP 86001-970 Londrina, PR, Brazil. E-mail: delmira@pr.gov.br

${ }^{3}$ Agronomist, M.Sc., IAPAR.

${ }^{4}$ Biologist, Dr., IAPAR. because rainfall exceeds evapotranspiration. Soil acidity can either be accelerated by soil degradation processes (soil erosion, nutrient depletion by leaching and runoff, organic matter mineralization, etc.) or be slowed down by soil conservation practices (terracing, contour farming, improved nutrient cycling and residue management, etc.).

The traditional coffee farming in Paraná is characterized by low planting density (high spacing between trees), which has contributed to increase 
soil erosion and consequently resulted in losses of organic matter and plant nutrients (Rufino et al., 1985). Soil erosion and nutrient leaching are the main causes to accelerate acidification of coffee soils. In some coffee areas of the State of Paraná, the low plant population system has generated such a high soil erosion and acidity, that coffee cultivation has had to be abandoned.

It is well known that increasing soil acidity decrease coffee productivity unless control measures are applied. Liming is the most common practice to improve soil fertility levels for coffee production in acid soils of Paraná (Chaves et al., 1984). The biological means of overcoming soil acidity problems have been proposed by Pavan et al. (1986a), who emphasized the merits of grass mulch covering the soil surface between coffee tree rows, and by Miyazawa et al. (1993) who favored the additions of plant residues.

Recently, a new coffee planting system with higher population density per unity of area has been proposed to increase coffee productivity in Paraná (IAPAR, 1991). The authors discussed the merits of the higher coffee population approach based on protecting soil from erosion. Increasing coffee population increases soil cover by the tree canopy and by plant residue on the soil surface which forms an organic layer $5-10 \mathrm{~cm}$ high. The changes in soil fertility status under different systems of coffee population densities have not yet been investigated in Brazil.

The purpose of this paper was to report the effects of different coffee population densities on some chemical, physical, and microbiological properties of soil.

\section{MATERIAL AND METHODS}

Soil samples were collected in an experimental site used for coffee tree spacing studies during 15 years (Siqueira et al., 1985). The land was used for grain crop production until 1977 when it was plowed in preparation for planting coffee (Coffea arabica L.) cv. Catuaí Vermelho, in a Typic Haplorthox located at Instituto Agronômico do Paraná (IAPAR) experimental station at Londrina

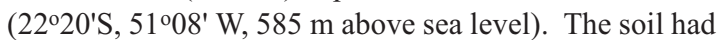
an original $\mathrm{pH}\left(\mathrm{H}_{2} \mathrm{O}\right)$ value of 4.4; exchangeable $\mathrm{Al}$, $\mathrm{Ca}$, $\mathrm{Mg}$, and $\mathrm{K}$ contents of 1.30, 2.32, 0.55 and $0.27 \mathrm{cmol}_{\mathrm{c}} \mathrm{dm}^{-3}$, respectively; extractable P content of $4.2 \mathrm{mg} \mathrm{kg}^{-1}$, and total organic carbon content of $13 \mathrm{~g} \mathrm{~kg}^{-1}$. Soil textural class of the $0-20 \mathrm{~cm}$ layer was clayey ( $81 \%$ clay, $13 \%$ silt, $6 \%$ sand) and bulk density was $1.0 \mathrm{~kg} \mathrm{~m}^{-3}$. These initial measurements indicated that soil acidity and insufficient extractable $\mathrm{P}$ levels were the chief soil constraints for coffee production.

The plant population treatments were as follows: 7143, 3571, 2381, 1786, 1429, 1190, 1020, and 893 trees/ha. The experimental field design was a randomized complete block with four replications. Other relevant informations of the experimental site and coffee managements were published before (Siqueira et al., 1985). Basic fertilizer additions in solid forms were also made to the soil. The fertilizer rates $(\mathrm{kg} / \mathrm{ha})$ of $\mathrm{N}, \mathrm{P}_{2} \mathrm{O}_{5}$, and $\mathrm{K}_{2} \mathrm{O}$ and years grown were: $60,100,80$ at planting time $1977 ; 40,0,0$ in $77 / 78 ; 60,0,30$, in $78 / 79 ; 80,0,40$, in $79 / 80$; and from 1980 to the end of the experiment, $150,80,140$, except in $81 / 82$ when no fertilizers were applied due to severe frost damage. The fertilizer sources were urea, single superphosphate, and potassium chloride.

Before planting operations, dolomite lime was applied on a whole plot basis and incorporated in two separated operations: firstly half of the rate was surface broadcasted and the soil plowed approximately $20 \mathrm{~cm}$ deep; secondly half of the rate was applied on soil surface as uniformly as possible to each plot, then the soil was harrowed to approximately $10 \mathrm{~cm}$ deep. The lime requirement was calculated as: $\mathrm{LR}\left(\mathrm{Mg} \mathrm{ha}^{-1}\right)=2 \times \mathrm{Al}=2 \times 1.3=2.6 \mathrm{Mg} \mathrm{ha}^{-1}$.

Soil samples were taken every year after harvesting operations during the experimental period by auger from 0-20 cm depth at four positions near the edge of the tree canopy in each treatment plot, and they were composed to obtain a single sample for analysis. By simplicity and due to the long time effect of plant population management on soil fertility, only the cumulative changes after 15 years were presented in this work.

Each soil sample was divided into four portions: for chemical analysis (Pavan et al., 1992); for volumetric soil moisture content; for microbial biomass with change in incubation time during three days (Jenkinson \& Powlson, 1976), and for mycorrhizal fungi analysis (Schenk, 1982). Volumetric soil moisture, microbial biomass and mycorrhizal fungi were analyzed in three treatments only: highest coffee population (7143 trees/ha), medium coffee population (1429 trees/ha) and lowest coffee population (893 trees/ha).

Data were analyzed using analysis of variance procedures (SAS , 1985). Means of soil chemical properties ( $\mathrm{pH}, \mathrm{Al}, \mathrm{Ca}, \mathrm{Mg}, \mathrm{K}, \mathrm{P}$ and $\mathrm{C}$ ) were compared by using 
LSD test and soil microbiological means by Tukey's multiple range test, all of them at $\mathrm{P}=0.05$.

\section{RESULTS AND DISCUSSION}

The results showed that the management of coffee population affected the concentration of soil organic carbon (Fig. 1). After 15 years, the organic carbon significantly increased under the highest plant population (from $13.0 \mathrm{~g} \mathrm{~kg}^{-1}$ to $14.5 \mathrm{~g} \mathrm{~kg}^{-1}$ ) and decreased under lower tree population (from $13.0 \mathrm{~g} \mathrm{~kg}^{-1}$ to $11.5 \mathrm{~g} \mathrm{~kg}^{-1}$ ) as compared with the original data $\left(\operatorname{LSD}_{0.05}=0.62 \mathrm{~g} \mathrm{~kg}^{-1}\right.$ ). The decrease in organic carbon with decreasing plant population suggests increases in losses by erosion and mineralization. The difference could be attributed to better erosion control and accumulation of residues on the soil surface by the higher plant population. The benefits of residues on the soil surface for coffee production in Paraná have been demonstrated before (Pavan et al., 1986a). The authors found that the average soil organic carbon was significantly higher under mulched than non-mulched plots.

A decrease in $\mathrm{pH}$ was observed with decreasing plant population density (Fig. 1$)\left(\mathrm{LSD}_{0.05}=0.46 \mathrm{pH}\right.$ unity). Probably, this effect was related to the nitrogen cycling. The additions of $\mathrm{NH}_{4}^{+}$or $\mathrm{R}-\mathrm{NH}_{2}$ based fertilizers on coffee soils generate two or one net $\mathrm{H}^{+}$ ions, respectively, by the oxidation reactions to $\mathrm{NO}_{3}$. These $\mathrm{H}^{+}$ions can be neutralized by the $\mathrm{N}$ cycle only if $\mathrm{NO}_{3}{ }^{-}$is absorbed by roots with release of $\mathrm{OH}^{-}$ions. If $\mathrm{NO}_{3}^{-}$is lost by leaching the $\mathrm{H}^{+}$ion remains as permanent soil acidity.

While the picture is not clear, two possible cases in the $\mathrm{N}$ cycle are suggested: a) high plant population decreases $\mathrm{NO}_{3}{ }^{-}$leaching, increases the amount of $\mathrm{NO}_{3}{ }^{-}$uptake by coffee roots, and increases the $\mathrm{OH}^{-}$ extruded into the rhizosphere, which might be used to neutralize $\mathrm{H}^{+}$ions produced by oxidation of $\mathrm{NH}_{4}{ }^{+}$ to $\mathrm{NO}_{3}^{-}$; and b) low plant population increases the quantities of $\mathrm{NO}_{3}^{-}$leached out and consequently decreases $\mathrm{NO}_{3}^{-}$uptake by coffee roots; in such system the excess of $\mathrm{H}^{+}$will remain in the soil as permanent acidity. Increasing $\mathrm{NO}_{3}^{-}$uptake also means increasing organic anions in the plant (R-COO-, R-O-) (Pierre \& Banwart, 1973) which return to soil upon decomposition of the plant leaves. The decrease in $\mathrm{NO}_{3}$ - leaching following increased uptake by coffee roots approach is supported by the data from Pavan et al. (1994), who demonstrated that high coffee population increases $\mathrm{N}$ use efficiency by increasing root population densities.

The $\mathrm{KCl}$ exchangeable Al decreased with increasing plant population (Fig. 1) $\left(\mathrm{LSD}_{0.05}=\right.$ $0.8 \mathrm{cmol}_{\mathrm{c}} \mathrm{dm}^{-3}$ ). Two possible mechanisms could be suggested: $\mathrm{pH}$ induced Al precipitation and complexation of Al by organic anions under higher plant population. Regardless of the mechanism, there is a great potential for decreasing $\mathrm{Al}$ availability to coffee by increasing plant population.

The levels of exchangeable $\mathrm{Ca}, \mathrm{Mg}$, and $\mathrm{K}$ increased with increasing plant population (Fig. 1) $\left(\mathrm{LSD}_{0.05}=2.1,0.3\right.$, and $0.08 \mathrm{cmol}_{\mathrm{c}} \mathrm{dm}^{-3}$, respectively). The accumulations of $\mathrm{Ca}, \mathrm{Mg}$, and $\mathrm{K}$ under high plant population are probably the results of decreasing nutrient losses by runoff and leaching and improved nutrient cycling. Under the lowest plant population the exchangeable cations declined to $20 \%$ on average bases, of the levels at the start of the experiment. The cation exchange capacity (CEC) calculated as the sum of exchangeable $\mathrm{Ca}, \mathrm{Mg}, \mathrm{K}$, and $\mathrm{Al}$ increased with increasing plant population.

The extractable $\mathrm{P}\left(0.05 \mathrm{~N} \mathrm{HCl}+0.025 \mathrm{~N} \mathrm{H}_{2} \mathrm{SO}_{4}\right)$ increased with increasing plant population (Fig. 1) $\left(\mathrm{LSD}_{0.05}=12.0 \mathrm{mg} \mathrm{kg}^{-1}\right)$. This was attributed to the effect of soil $\mathrm{pH}$ and organic matter content on the availability of P. Decreasing $\mathrm{pH}$ with decreasing plant population increased $\mathrm{P}$-adsorption largely from the precipitation as $\mathrm{AlPO}_{4}$ and $\mathrm{FePO}_{4}$ oxides. As pH increases with increasing plant population, the activity of $\mathrm{Fe}$ and $\mathrm{Al}$ decreases, which results in higher $\mathrm{P}$ concentration in solution. The effect of organic compounds on $\mathrm{P}$ availability is attributed by either the coating of $\mathrm{Fe}$ and $\mathrm{Al}$ particles by humus to form a protective cover or complexing Fe and Al by organic anions produced from the decomposition of organic matter (Sample et al., 1980), thus preventing their reaction with $\mathrm{H}_{2} \mathrm{PO}_{4}^{-}$. This hypothesis is supported by the work from Pavan \& Chaves (1996) who found that increasing soil $\mathrm{pH}$ and organic matter under high tree population density were the main factors in $\mathrm{P}$ availability in coffee soils. 

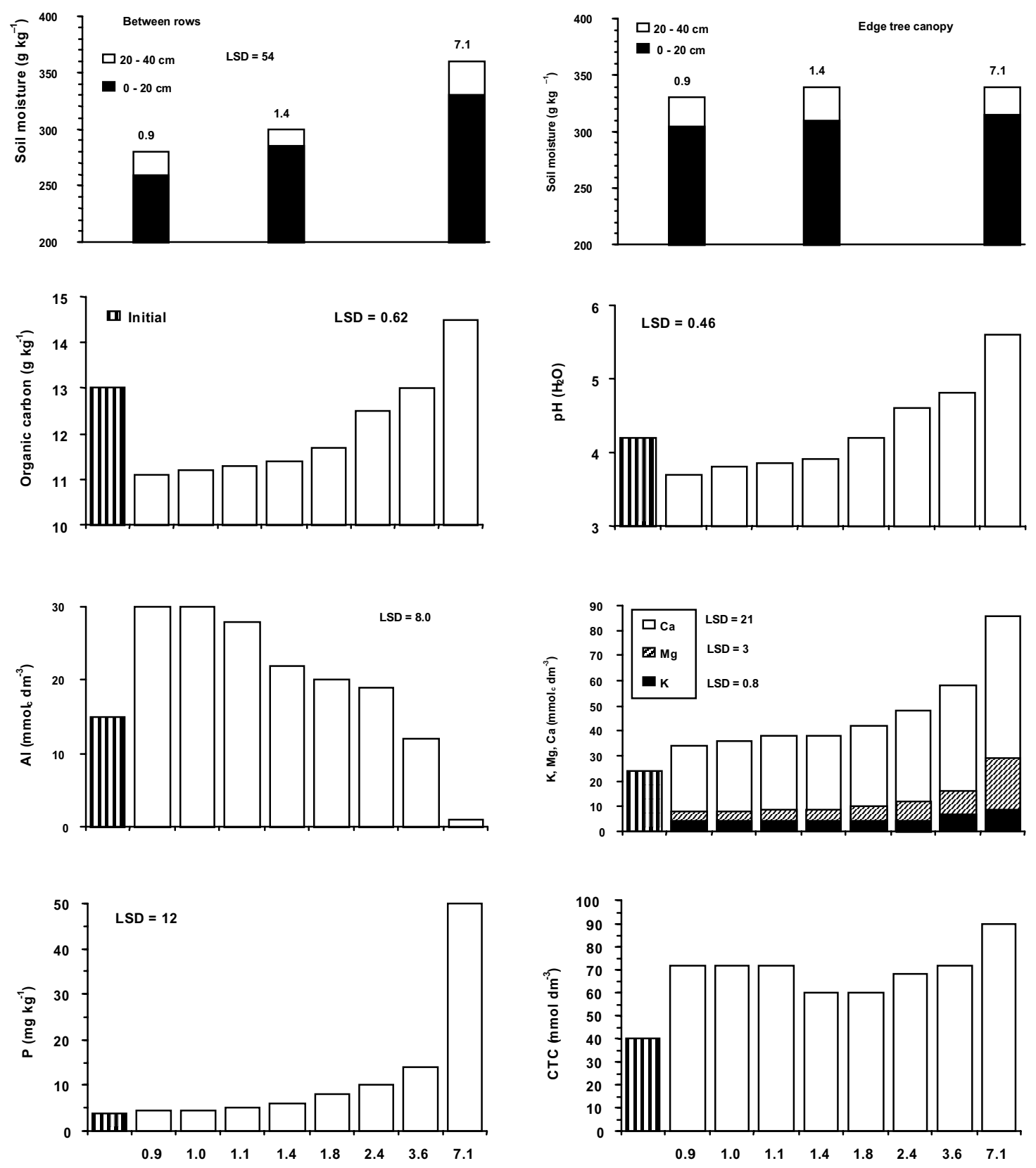

Plant population (trees/ha $\times 1000)$

FIG. 1. Effect of coffee tree population on some chemical properties of soil. The numbers at the top of each column represent plant population densities. 
Increasing residue on the soil surface with increasing plant population reduces erosion while increasing water storage in both $0-20 \mathrm{~cm}$ and $20-40 \mathrm{~cm}$ soil depth (Fig. 1$)\left(\mathrm{LSD}_{0.05}=5.4 \%\right)$. The difference in water content was higher near the edge of the tree canopy than inter tree row zone. The water stored in soil is an important factor determining the yield potential and may explain the increase in yields with increasing plant population (Siqueira et al., 1985). As water is the medium of nutrient transport to the roots it also may explain the better nutrient status of the coffee tree under high population density (Pavan et al., 1994). Pavan et al. (1986b) found that native $\mathrm{Zn}$ uptake by coffee roots also increased with increasing soil moisture content. The authors emphasized the importance of soil moisture in the interpretation of $\mathrm{Zn}$ soil test data for coffee in the definition of critical levels of $\mathrm{Zn}$ availability.

The concentration of carbon $(\mathrm{C})$ in the soil microbial biomass decreased with increasing plant population (Table 1). This result may explain the accumulation of total organic $\mathrm{C}$ under high plant population (Fig. 1). The decrease of microbial biomass with increasing plant populations was probably due to decrease light intensity and temperature on the soil surface. The results of microbial biomass production in coffee plantation in Paraná (Table 1) were much lower than those reported by Rodrigues et al. (1994) under tropical environment (from 9 to $265 \mathrm{~g} \mathrm{mg} \mathrm{C/g} \mathrm{soil).} \mathrm{It} \mathrm{is} \mathrm{important} \mathrm{to}$ consider that in the work by Rodrigues et al. (1994) ten days of incubation time were used, instead of three days used in the present work. Balota (1997) also used three days of incubation time and found that biomass varied from 30 to $550 \mathrm{mg} \mathrm{C} / \mathrm{g}$ soil, depending on soil management, crop species, and sampling time.
Although the fumigation-incubation method presents restrictions in relation to fumigationextraction method for soils with recent additions of organic materials (Jenkinson \& Powlson, 1976), a high correlation coefficient between both methodologies has been reported for several soil types under temperate climate (Tate et al., 1988) and tropical climate (Rodrigues et al., 1994).

The percentage of coffee roots colonized by vesicular arbuscular mycorrhizal (VAM) fungi increased and the number of VAM spores in soil decreased with increasing plant population (Table 1). The improvement of soil fertility conditions, especially the increase of $\mathrm{pH}$, availability of $\mathrm{P}, \mathrm{Ca}$, $\mathrm{Mg}$ and $\mathrm{K}$, and soil moisture provided favorable environment for plant and fungi development, thus promoting mycorrhization. The higher plant population and consequent higher root density probably increased root infection through mycelial diffusion among plants, which ultimately increased root colonization. The data of root colonization by VAM presented in Table 1 were much lower than those reported by Siqueira \& Colozzi-Filho (1986). Based on data found by Siqueira \& Colozzi-Filho (1986) these lower levels of root colonization presented in Table 1 are not sufficient to improve coffee nutrition. They also found that $\mathrm{P}$ availability in soil for maximum efficiency of VAM colonization (30-35\%) ranges from 10 to $100 \mathrm{mg} / \mathrm{g}$. Below $10 \mathrm{mgP} / \mathrm{g}$ soil mycorrhization may cause parasitic effect and above $100 \mathrm{mg} \mathrm{P} / \mathrm{g}$ soil depressive effect on plant growth.

In the present work soil $\mathrm{P}$ increased from 4 to $50 \mathrm{mg} / \mathrm{g}$ as increased plant population density (Fig. 1) which are favorable P-fertility for root colonization.

TABLE 1. Effect of coffee tree population on microbial biomass and on vesicular arbuscular mycorrhizal fungi (VAM) of soil.

\begin{tabular}{cccc}
\hline $\begin{array}{c}\text { Plant population } \\
\text { (trees/ha) }\end{array}$ & $\begin{array}{c}\text { Microbial } \\
\text { biomass } \\
(\mu \mathrm{g} \mathrm{C} / \mathrm{g} \text { soil })\end{array}$ & $\begin{array}{c}\text { VAM fungi } \\
\text { root colonization } \\
(\%)\end{array}$ & $\begin{array}{c}\text { VAM fungi } \\
\left(\mathrm{n}^{\mathrm{O}} \mathrm{spores} / 50 \mathrm{~mL}\right)\end{array}$ \\
\hline 7,143 & $5.26 \mathrm{~b}$ & $29.68 \mathrm{a}$ & $4.31 \mathrm{~b}$ \\
1,429 & $7.41 \mathrm{~b}$ & $20.30 \mathrm{ab}$ & $8.52 \mathrm{ab}$ \\
$18.31 \mathrm{a}$ & $19.19 \mathrm{~b}$ \\
\hline $\mathrm{CV}(\%)$ & $16.87 \mathrm{a}$ & 18 & 14 \\
\hline
\end{tabular}


The low coffee root colonization after 15 years, despite of favorable soil-P levels for mycorrhizal growth, may be due to the effect of mono-cropping in selecting VAM species less efficient (Johnson \& Pfleger, 1992). The occurrence of lower sporulation in the soil is an indirect indicator of better mycorrhizal status in the high density planting system.

The soils of Paraná are highly weathered, kaolinitic, and variable charge type (Pavan et al., 1985). In such system as $\mathrm{pH}$ decreases net negative charge approaches zero and CEC decreases, and there is an increase in nutrient leaching and immobilization and exchangeable $\mathrm{Al}$ increases (Pavan et al., 1985). Traditional coffee farming in Paraná with low coffee tree population per unit of area has led to increased erosion, nutrient depletion by runoff and leaching, and loss of organic matter, which are the main causes for soil acidification (Rufino et al., 1985; IAPAR, 1991).

High coffee population, on the other hand, is a planting system that reduces soil and water losses and where all crop residues are returned to the soil as compared with low plant population (Siqueira et al., 1985; IAPAR, 1991). Improved residue management, water conservation, soil structure, nutrient cycling and decreased soil acidification, organic matter mineralization, nutrient leaching and runoff were important reasons for recommending higher coffee population density in Paraná (Siqueira et al., 1985; IAPAR, 1991; Pavan et al., 1994). These changes under high population densities have led to increased soil $\mathrm{pH}$, cation exchange capacity, base saturation, organic matter content, and decreased toxic levels of Al. As a result, high coffee population is a system that may help to improve soil fertility. Therefore, coffee growers must take advantage of this technology not only to increase yields and to minimize soil nutrients and organic matter losses but also to increase soil fertility.

\section{CONCLUSIONS}

1. High coffee population increases soil organic matter and soil nutrient availability and reduces soil acidity.
2. High coffee population is an alternative system to improve soil fertility.

\section{REFERENCES}

BALOTA, E.L. Alterações microbiológicas em solo cultivado sob o plantio direto. In: PEIXOTO, R.T.G.; AHRENS, D.C.; SAMAHA, M.J. (Eds.). Plantio direto: caminho para uma agricultura sustentável. Ponta Grossa: IAPAR, PRP/PG, 1997. p.222-233.

CHAVES, J.C.D.; PAVAN, M.A.; IGUE, K. Respostas do cafeeiro à calagem. Pesquisa Agropecuária Brasileira, Brasília, v.19, n.5, p.573-582, maio 1984.

IAPAR. Modelo tecnológico para o café no Paraná. Londrina, 1991. 14p. (IAPAR. Informe da Pesquisa, 97).

JENKINSON, D.S.; POWLSON, D.S. The effects of biocidal treatments on metabolism in soil. V. A method to measuring soil biomass. Soil Biology $\boldsymbol{\&}$ Biochemistry, Oxford, v.8, n.3, p.209-213, 1976.

JOHNSON, N.C.; PFLEGER, F.L. Vesicular-arbuscular mycorrhizae and cultural stresses. In: BETHLENFALVAY, G.J.; LINDERMAN, R.G. (Eds.). Mycorrhizae in sustainable agriculture. Madison: American Society of Agronomy, 1992. p.71-99.

MIYAZAWA, M.; PAVAN, M.A.; CALEGARI, A. Efeito de material vegetal na acidez do solo. Revista Brasileira de Ciência do Solo, Campinas, v.17, n.3, p.411-416, 1993.

PAVAN, M.A.; BINGHAM, F.T.; PRATT, P.F. Chemical mineralogical characteristics of selected acid soils of the state of Paraná, Brazil. Turrialba, San Jose, v.35, n.2, p.131-139, 1985.

PAVAN, M.A.; BLOCH, M.M. de F.; ZEMPULSKI, H. de C.; MIYAZAWA, M.; ZOCOLER, D.C. Manual de análise química de solo e controle de qualidade. Londrina: IAPAR, 1992. 40p. (IAPAR. Circular, 76).

PAVAN, M.A.; CARAMORI, P.H.; ANDROCIOLI FILHO, A.; SCHOLZ, M.F. Manejo da cobertura do solo para formação e produção de uma lavoura cafeeira. I. Influência na fertilidade do solo. Pesquisa Agropecuária Brasileira, Brasília, v.21, n.2, p.187-192, fev. 1986a.

PAVAN, M.A.; CHAVES, J.C.D Alterações nas frações de fósforo no solo associadas à densidade 
populacional de cafeeiros. Revista Brasileira de Ciência do Solo, Campinas, v.20, p.251-256, 1996.

PAVAN, M.A.; CHAVES, J.C.D.; ANDROCIOLI FILHO, A. Produção de café em função da densidade de plantio, adubação e tratamento fitossanitário. Turrialba San Jose, v.44, n.4, p.227-231, 1994.

PAVAN, M.A.; SIQUEIRA, R.; FARIA, R.T. de; MACHADO, P.L.O. de A.; MIYAZAWA, M. Influência da umidade do solo no diagnóstico da deficiência de zinco em cafeeiros. Ciência e Cultura, São Paulo, v.38, n.6, p.1695-1699, 1986b.

PIERRE, W.H.; BANWART, W.L. Excess-base and excessbase/nitrogen ratio of various crop species and part of plants. Agronomy Journal, Madison, v.65, n.1, p.91-96, 1973

RODRIGUES, E.F.; GUERRA, J.G.M.; ALMEIDA, D.L.; DE-POLLI, H. Biomassa microbiana de carbono de solo de Itaguaí (RJ): comparação entre os métodos fumigação-incubação e fumigação-extração. Revista Brasileira de Ciência do Solo, Campinas, v.18, p.427-432, 1994.

RUFINO, R.L.; HENKLAIN, J.C.; BISCAIA, R.C.M. Influência das práticas de manejo e cobertura vegetal do cafeeiro nas perdas de solo. Revista Brasileira de Ciência do Solo, Campinas, v.9, n.4, p.573-582, 1985.
SAMPLE, E.C.; SOPER, R.J.; RACZ, G.J. Reaction of phosphate fertilizers in soils. In: KHASAWNEH, F.E. (Ed.). The role of phosphorus in Agriculture. Madison: American Society of Agronomy, 1980. p.263-310

SAS INSTITUTE INC. SAS/STAT user's guide. Version 6. 4.ed. Cary, 1985. v.1, 890p.

SCHENK, N.C.(Ed.). Methods and principles of mycorrhizal research. 19.ed. St. Paul: American Phytopathological Society, 1982. 250p.

SIQUEIRA, J.O.; COLOZZI-FILHO, A. Micorrizas vesículo-arbusculares em mudas de cafeeiro. II. Efeito do fósforo no estabelecimento e funcionamento da simbiose. Revista Brasileira de Ciência do Solo, Campinas, v.10, p.207-211, 1986.

SIQUEIRA, R.; ANDROCIOLI FILHO, A.; CARAMORI, P.H.; PAVAN, M.A. Espaçamento e produtividade do cafeeiro. Londrina: IAPAR, 1985. 6p. (IAPAR. Informe da Pesquisa, 56).

TATE, K.R.; ROSS, D.J.; FELTHAM, C.W. A direct extraction method to estimate soil microbial C: effects of experimental variables and some different calibration procedures. Soil Biology \& Biochemistry, Oxford, v.20, n.3, p.329-335, 1988. 